\title{
Frontal Sinus Inverted Papilloma
}

National Cancer Institute

\section{Source}

National Cancer Institute. Frontal Sinus Inverted Papilloma. NCI Thesaurus. Code C6842.

A benign neoplasm that arises from the ciliated respiratory mucosa that lines the frontal sinus. It results from the invagination and proliferation of epithelial cells in the underlying stroma. 